\title{
The Effects to GM-CSF Expression and Fibroblast Proliferation of pGM- CSF Containing Chitosan/PVP Hydrogels
}

\author{
Emine Şalva, Jülide Akbuğa
}

\begin{abstract}
The aim of this study was to develop pGM-CSF containing chitosan/PVP hydrogel system for gene delivery. The hydrogels in semi-interpenetrating polymer network (semi-IPN) structure were synthesized by glutaraldehyde crosslinking between $2 \%$ chitosan and 2\%, \%4, \%6 PVP. The viscosity, swelling properties and surface morphology of hydrogels were examined. These hydrogels showed highly porous structure. The porosity was increased with enhanced PVP concentration. Viscosity decreased with increasing PVP concentration of the hydrogels. The swelling percentage increased with increasing PVP concentration. In order to examine the effect of cell
\end{abstract}

attachment and proliferation of hydrogels, NIH-3T3 fibroblast cell was used. The cells were able to attach on the top surface of hydrogels. However, the attachment of cells were slow at days 1 and 3. At days 7 and 14, cells looked healthy and normal and proliferated around and top of the hydrogels. With the ELISA study, the highest GM-CSF expression was obtained with pGM-CSF containing $2 \%$ chitosan $+4 \%$ PVP hydrogels. MTT assay showed that chitosan/PVP hydrogels did not induce significant cytotoxic effect. As a result, these hydrogels could be served candidate for local gene delivery in tissue regeneration.

Key Words: pGM-CSF, chitosan, PVP, hydrogel, gene delivery
Emine Şalva

İnönü University, Faculty of Pharmacy, Department of Pharmaceutical Biotechnology, Malatya, TURKEY

Jülide Akbuğa

Marmara University, Faculty of Pharmacy, Department of Pharmaceutical Biotechnology, İstanbul, TURKEY

Corresponding Author:

Emine Şalva

e-mail:emine.salva@inonu.edu.tr
Submitted / Gönderilme: 10.10 .2016

Accepted / Kabul: 17.11.2016

Revised / Düzeltme: 15.11.2016

\section{INTRODUCTION}

Hydrogels have three-dimensional structure that are similar to the extracellular matrix (ECM). The cross-linked hydrophilic polymer network structure of hydrogel is capable of swelling in biological fluids and water $(1,2)$. The swollen hydrogels have elastic characteristic and thus they can easily be applied to normal or damaged tissue. Hydrogels have been used for local and sustained delivery of many therapeutics, ranging from small molecular weight drugs to biomolecules, such as proteins and nucleic acids (2). Hydrogels are prepared with variety of natural and synthetic polymers. Among of these, chitosan hydrogels have been preferred due to the polymer's desirable properties such as biodegradability, biocompatibility, mucoadhesivity, non-toxicity and lowimmunogenicity $(1,3,4)$. Chitosan has been used as dressing and accelerator natural biopolymer in wound healing for a long time. Polyvinyl pyrrolidone (PVP) is a synthetic, nontoxic, biocompatible and hydrophilic polymer that has been used as bioadhesive wound dressing matrix. PVP hydrogels 
have attracted much attention in controlled drug release systems, wound dressings and tissue engineering (5).

Chitosan/PVP hydrogels have firstly been synthesized for wound healing and controlled drug release by Risbud et al (5). These hydrogels have favorable properties of both polymers. PVP/chitosan hydrogels have high mechanical strengths, hydrophilicity and water content and also high swelling behaviour due to the porosity of structures. Risbud et al. showed that while chitosan-PVP hydrogels were strongly inhibiting fibroblast growth and proliferation by preventing their attachment on the surface, these hydrogels increased the attachment and growth of epithelial cells (5). They suggested that chitosan/PVP hydrogels could be used for reducing the excessive fibrosis in wound healing. Anjum et al. studied chitosan-PEG/PVP hydrogels as antimicrobial and scar preventive wound dressing (6). Tetracycline loaded hydrogels could have a good antimicrobial nature and provide scar preventive wound healing.

Granulocyte macrophage colony stimulating factor (GMCSF) is a pleiotropic cytokine that is secreted mainly by keratinocytes and other cells including macrophages, lymphocytes, fibroblasts, endothelial cells and dendritic cells during wound repair. Many studies reported that the administration of this cytokine onto the wound area had accelerated the wound healing. The delivery of growth factor expressing genes is an attractive method for the wound healing. In this approach, cells produce the protein through the delivery of DNA that encodes the needed protein in wound area and thus pDNA can be continuous source of the growth factor (7). In many studies, naked or complexed DNA have been incorporated into hydrogel scaffolds such as hyaluronic acid, chitosan, collagen and co-polymers with PEG and other polymers of these (7). However, pDNA incorporated chitosan/PVP hydrogels firstly investigated by our group. In the previous study, we showed the enhanced cell proliferation of pGM-CSF containing chitosan complexes (8). In the present study, we investigated effects to the modulation of fibroblast cells and gene delivery of pGMCSF containing chitosan/PVP hydrogels.

\section{MATERIALS AND METHODS}

\section{Materials}

Chitosan (Medium MW; 190-310 kDa) was supplied by Sigma (Germany). PVP (K29-32) was purchased from Sigma (Germany). MTT cell proliferation kit was from Roche (Germany). pORF-hGM-CSF plasmid DNA was supplied from InvivoGen (San Diego, USA). hGM-CSF ELISA kit was purchased from Ebiosciences (San Diego, USA). All of the cell culture media and reagents were purchased from Biological Industries (Israel). All other chemicals used were of molecular grade.

\section{Plasmid DNA Isolation and Preparation of pGM-CSF- Loaded Chitosan/PVP Hydrogels}

The pORF-hGM-CSF containing human GM-CSF gene under control of SV40 promoter is $3650 \mathrm{bp}$. Plasmid DNA was isolated according to the manufacturer's instructions (Roche, Germany). Then, the quantity and quality of the purified plasmid DNA were assessed spectrophotometrically at $260-280 \mathrm{~nm}$ and also by electrophoresis in agarose gels.

For preparing chitosan/PVP hydrogels, chitosan $(2 \% \mathrm{w} / \mathrm{v})$ was dissolved in acetic acid and PVP was dissolved in bidistilled water. Different concentrations of PVP solutions $(2 \%, 4 \%$ and $6 \% \mathrm{w} / \mathrm{v})$ were prepared fort he formulations. Then all the solutions were filtered $(0.22 \mu \mathrm{m})$ for sterilization. pDNA $(500 \mu \mathrm{g})$ was added into the PVP solutions. pDNA containing PVP solutions (2\%, $4 \%$ and $6 \%$ ) were added to the chitosan solution (2\%) and the stirring continued until getting homogenous mixtures. A glutaraldehyde reagent $(0,05 \%)$ was added as a crosslinking agent to the solutions and stirred at room temperature for one hour for preparing hydrogels in semi-interpenetrating polymer network (IPN) structure. The gel-like solution was poured into a sterile petri dish. The hydrogels were allowed to dry at room temperature for swelling study. pGM-CSF loaded chitosan/PVP hydrogels were controlled by $0.7 \%$ agarose gel electrophoresis.

Table 1. Viscosity measurements of hydrogels.

\begin{tabular}{ll} 
Formulation & Viscosity (cp) \\
\hline $2 \%$ Chitosan & 561 \\
$2 \%$ Chitosan+ $\%$ PVP & 245 \\
$2 \%$ Chitosan+4\% PVP & 218 \\
$2 \%$ Chitosan+6\% PVP & 193
\end{tabular}

\section{Morphology of the Chitosan/PVP Hydrogels}

Prior to scanning electron microscopy (SEM) analysis, hydrogels in petri dishes were stored at $-80^{\circ} \mathrm{C}$ and dehydrated 
using lyophilization. The samples were coated with gold and imaged using SEM.

\section{Viscosity Measurement}

The viscosities of the hydrogels were measured using digital rotational Brookfield Viscometer (USA). All measuremets were carried out at $25^{\circ} \mathrm{C}$. The shearing time was $60 \mathrm{~s}$. Each experiment was carried out three times.

\section{Swelling Study}

For the determination of swelling behaviour of the samples, hydrogels were weighted and distilled water was added to the formulations. After that, hydrogels were blotted with absorbent paper to remove the water adhering on the sample surface. The wet samples were weighted and at predetermined time intervals the water in samples were removed by filter paper and reweighed. The swelling ratio was calculated by the following equation;

$$
\text { Swelling }(\%)=(\text { Ws-Wd }) / \text { Ws } x 100
$$

where $\mathrm{Wd}$ and $\mathrm{Ws}$ are the weight of the dry and wet samples, respectively $(9,10)$.

\section{Cell Culture and Seeding}

NIH 3T3 continuous mouse fibroblast cell line was cultured in Dulbecco's Modified Eagle Medium (DMEM). The culture was incubated at $37^{\circ} \mathrm{C}$ in a $5 \% \mathrm{CO}_{2}$ in air atmosphere. $1 \mathrm{ml}$ hydrogel was placed to the 6 well plate and exposed to UV irridiation for sterilization for $30 \mathrm{~min}$. pDNA containing hydrogel formulations were then rinsed with culture media to remove the residual glutaraldehyde. The cells were seeded onto the hydrogels at concentration $3 \times 10^{5}$ cells/well. After $72 \mathrm{~h}$ from transfection of pGM-CSF containing hydrogels, GM-CSF expression was measured by ELISA. The effect to cell viability and proliferation of hydrogels was examined by MTT method at days 3 and 7.

\section{The Determination of Released GM-CSF Amount}

ELISA for GM-CSF was performed in the medium according to the manufacturer's instructions (Biosciences, USA). GMCSF protein was analyzed using solid phase sandwich ELISA. Absorbance was measured by spectrophotometric reading at $450 \mathrm{~nm}$. All the experiments were repeated thrice and standard deviation $( \pm)$ was calculated.

\section{Cell Proliferation}

The separate 96 well plates were prepared for each sampling time point (days 3 and 7). Control wells without hydrogels and sample wells with hydrogels were prepared as described above. The cells in DMEM mixture were seeded in each well on top of the various hydrogels. After incubation at each sampling time point, MTT $(5 \mathrm{mg} / \mathrm{ml})$ was added to each well. After $4 \mathrm{~h}$, formed formazan crystals were dissolved in solubilization buffer. Absorbance was measured at $550 \mathrm{~nm}$ with background correction at $690 \mathrm{~nm}$ using spectrophotometer (Shimadzu, Japan).

\section{RESULTS AND DISCUSSION}

\section{Electrophoretic Study}

According to the agarose gel electrophoresis studies of chitosan/PVP hydrogels complexation was formed between cationic chitosan and anionic pDNA (Fig.1). pDNA loaded hydrogels could remain within the loading well. Fig. 1 showed entrapped pDNA into hydrogel in different chitosan/ PVP ratios. In many studies, naked or complexed DNA have been incorporated into hydrogel scaffolds such as chitosan and co-polymers with its PEG and other polymers (11-14). Lei et al. studied with the incorporation of active DNA/ PEI polyplexes into hydrogel scaffolds (14). Tokatlian et al. encapsulated VEGF gene containing plasmid into porous hyaluronic acid hydrogels to investigate scaffold-mediated local gene delivery in diabetic wound model (15).
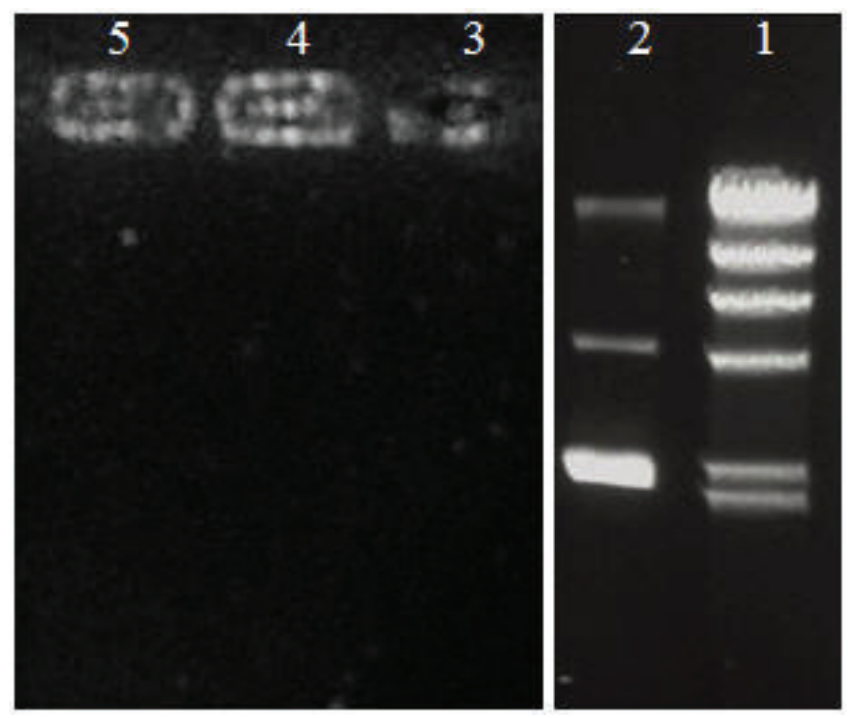

Figure 1. Agarose gel electrophoresis analysis of pGM-CSF loaded chitosan/PVP hydrogels. Lane 1. Hind III Lamda DNA marker, 2. Free pGM-CSF, 3. $2 \%$ chitosan+2\% PVP, 4. 2\% chitosan+4\%PVP, 5. $2 \%$ chitosan $+6 \%$ PVP hydrogels. 

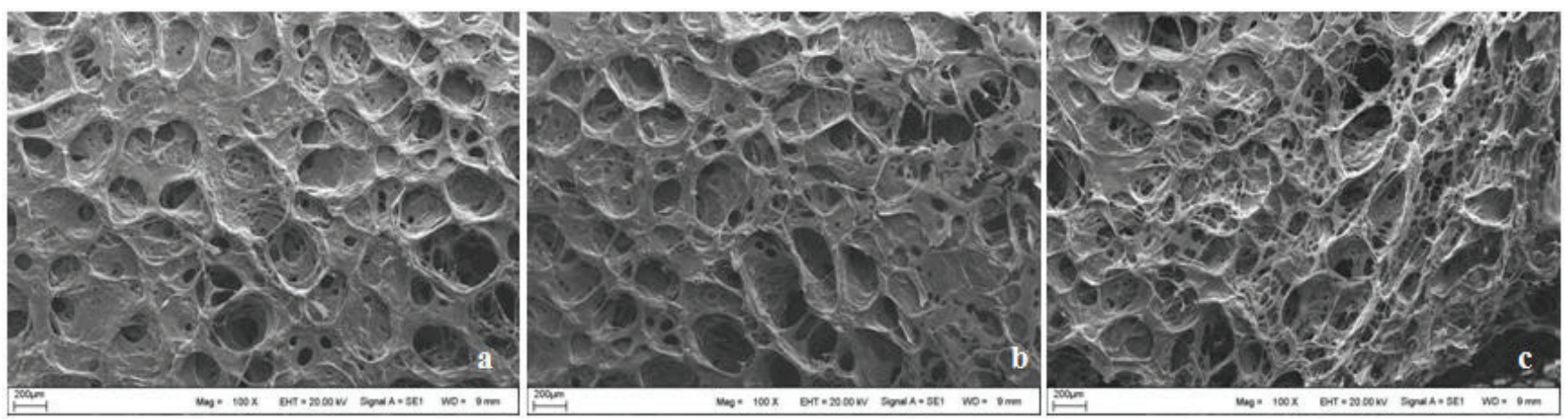

Figure 2. SEM images of chitosan/PVP hydrogels with the different PVP concentrations a. 2\%, b.4\%, c.6\%.

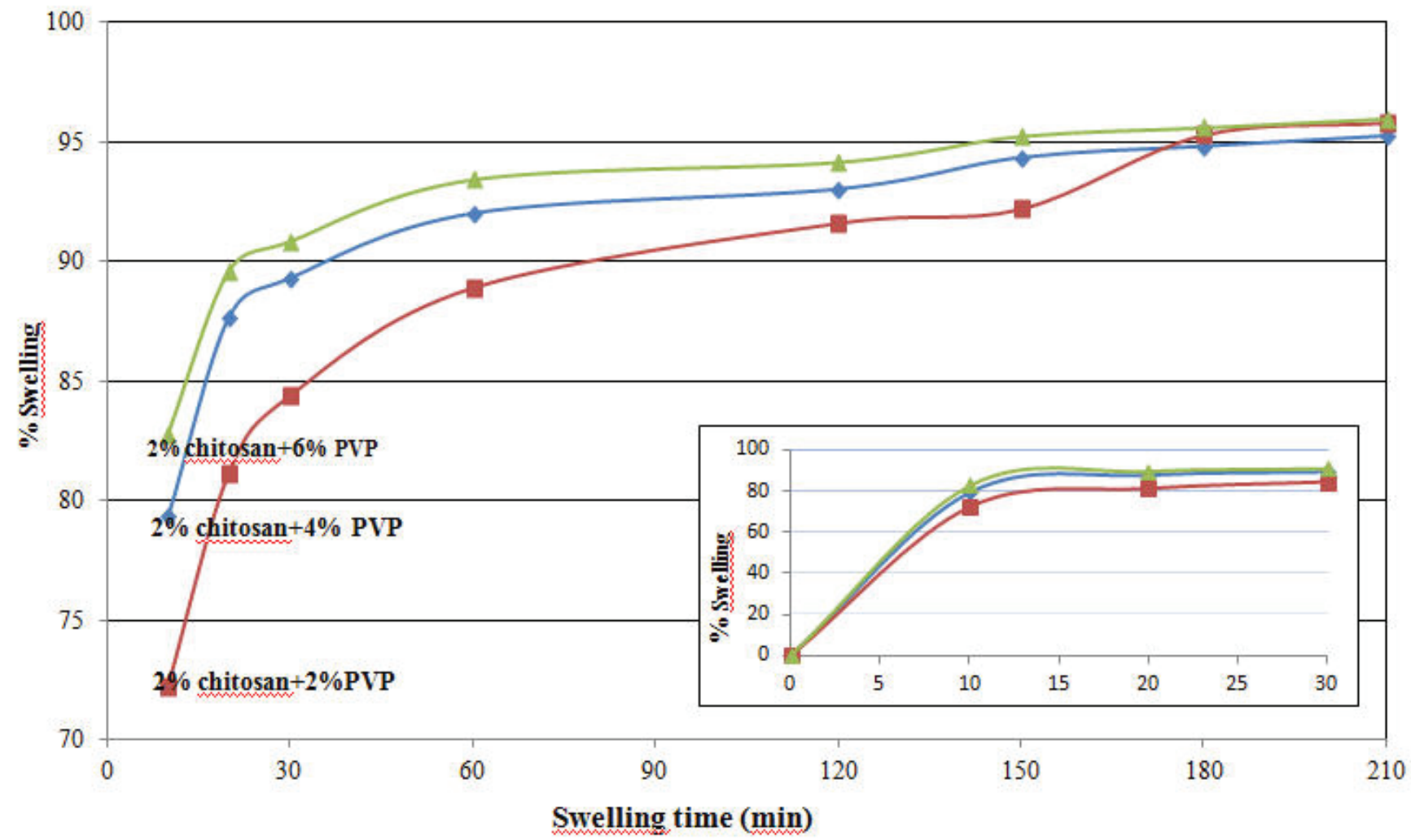

Figure 3. Swelling of chitosan/PVP hydrogels in different concentrations.

\section{Morphology Study}

The morphology of lyophilized hydrogels was studied using SEM. Surface morphology of hydrogels with the different PVP concentration was shown in Fig. 2. These hydrogels showed highly porous structure. The porosity was increased with enhanced PVP concentration. The porosity affects the swelling properties and also mechanical and biological characteristics of hydrogels (16). The porous structure of hydrogels is important for cell infiltration and growth (17).

\section{Viscosity Study}

The water-soluble polymer PVP has high solubility and biocompatibility characteristics (10). However, using PVP in hydrogels have been limited due to its poor mechanical properties. The more functional hydrogels could be produced by using chitosan with PVP polymer (18). The viscosity measurements of the chitosan/PVP hydrogels were shown in Table 1. Viscosity decreased with increasing PVP concentration in the hydrogels. It was found that chitosan/PVP hydrogels had appropriate viscosity, so these hydrogel formulations could be recommended as wound dressing material. 


\section{Swelling Study}

The swelling behaviour of chitosan/PVP hydrogels was measured in PBS to evaluate the extent of their water uptake property. The swelling behavior is one of the important properties of hydrogels (19). PVP forms strong hydrogen bonding with the chitosan chains. The hydrophilic natures of chitosan and PVP can be an important parameter for the extent of swelling ratio. The swelling property of hydrogels in different PVP/chitosan ratio was shown in Figure 3. The swelling percentage was increased with increasing PVP concentration. Zhang et al. reported that the degree of swelling had increased with PVP content because of high hydrophilic nature of PVP polymer (20).

\section{Cell Attachment Study}

In vitro cell culture studies were conducted to demonstrate the allowing cell attachment and penetration of chitosan/ PVP hydrogels (Fig. 4). The porosity of hydrogels facilitates nutrients and wastes exchange for cell proliferation and cells could penetrate into porous hydrogels easily (16). In our study, fibroblast cells were able to attach on the top surface of hydrogels. However, the attachment of cells were slow at days 1 and 3. At days 7 and 14, cells looked healthy and normal and proliferated around and top of the hydrogels.

\section{The Determination of GM-CSF Expression}

The encapsulation of growth factors or recombinant proteins into hydrogels has been widely used in tissue regeneration

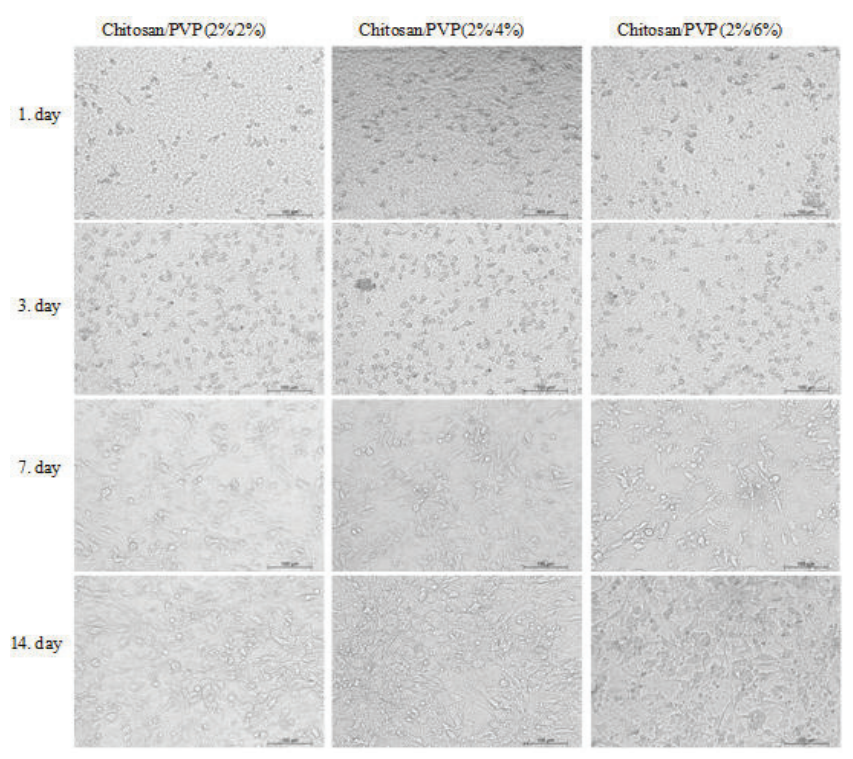

Figure 4 . The cell attachment study in the NIH-3T3 cells.

and cancer therapy. However, local delivery of DNA as an alternative to delivery of proteins through hydrogel provide advantage for long-term bioactivity and prolonged gene expression of encoded factor. In our study, the DNA delivery from pGM-CSF containing chitosan/PVP hydrogels was examined by determination of GM-CSF expression using ELISA in NIH-3T3 cells. After $72 \mathrm{~h}$ from transfection, the highest GM-CSF expression was obtained with pGM-CSF containing 2\% chitosan+4\% PVP hydrogels (Fig. 5).

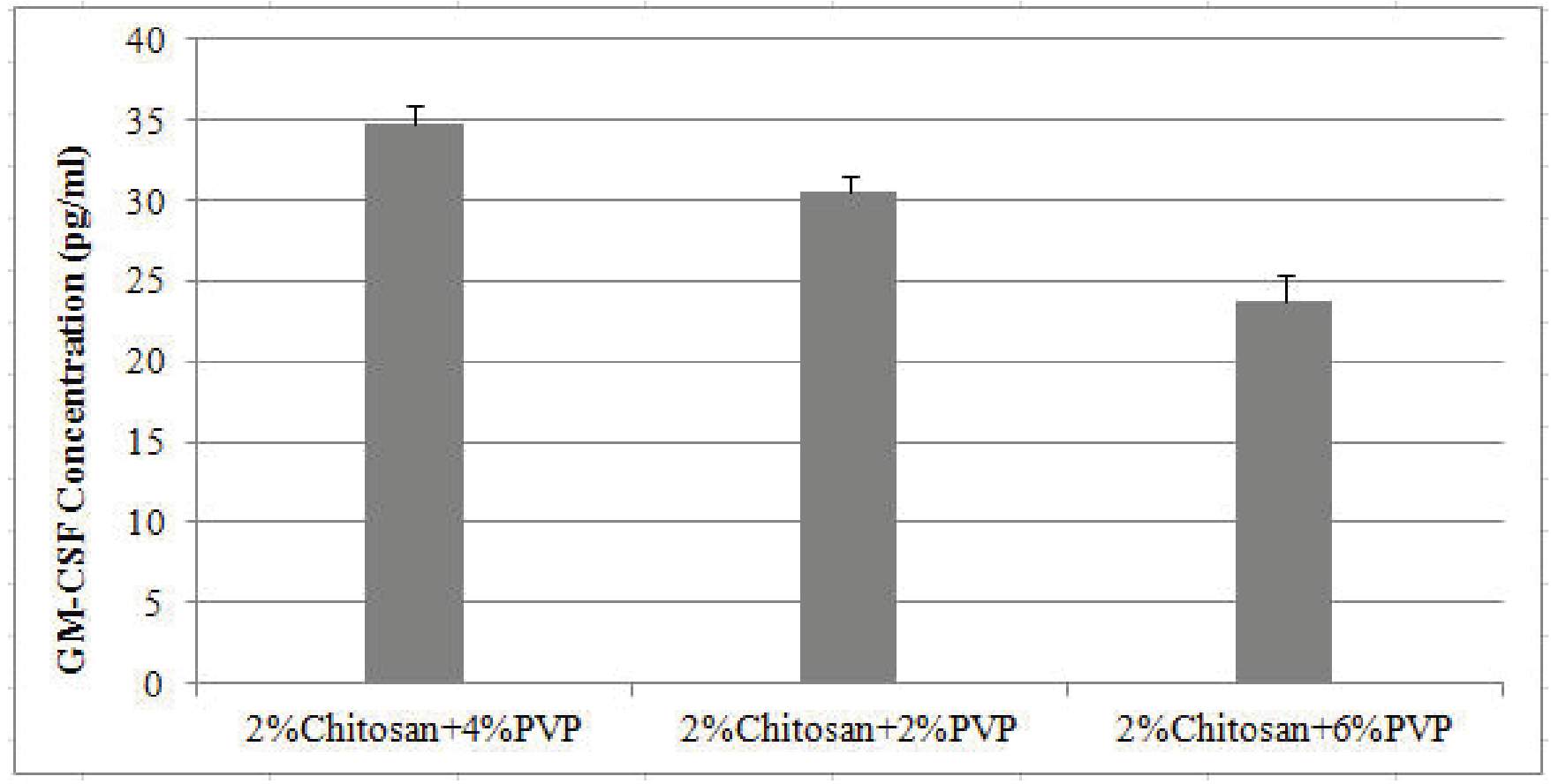

Figure 5. The ELISA study of pGM-CSF containing hydrogels in NIH-3T3 cells. 


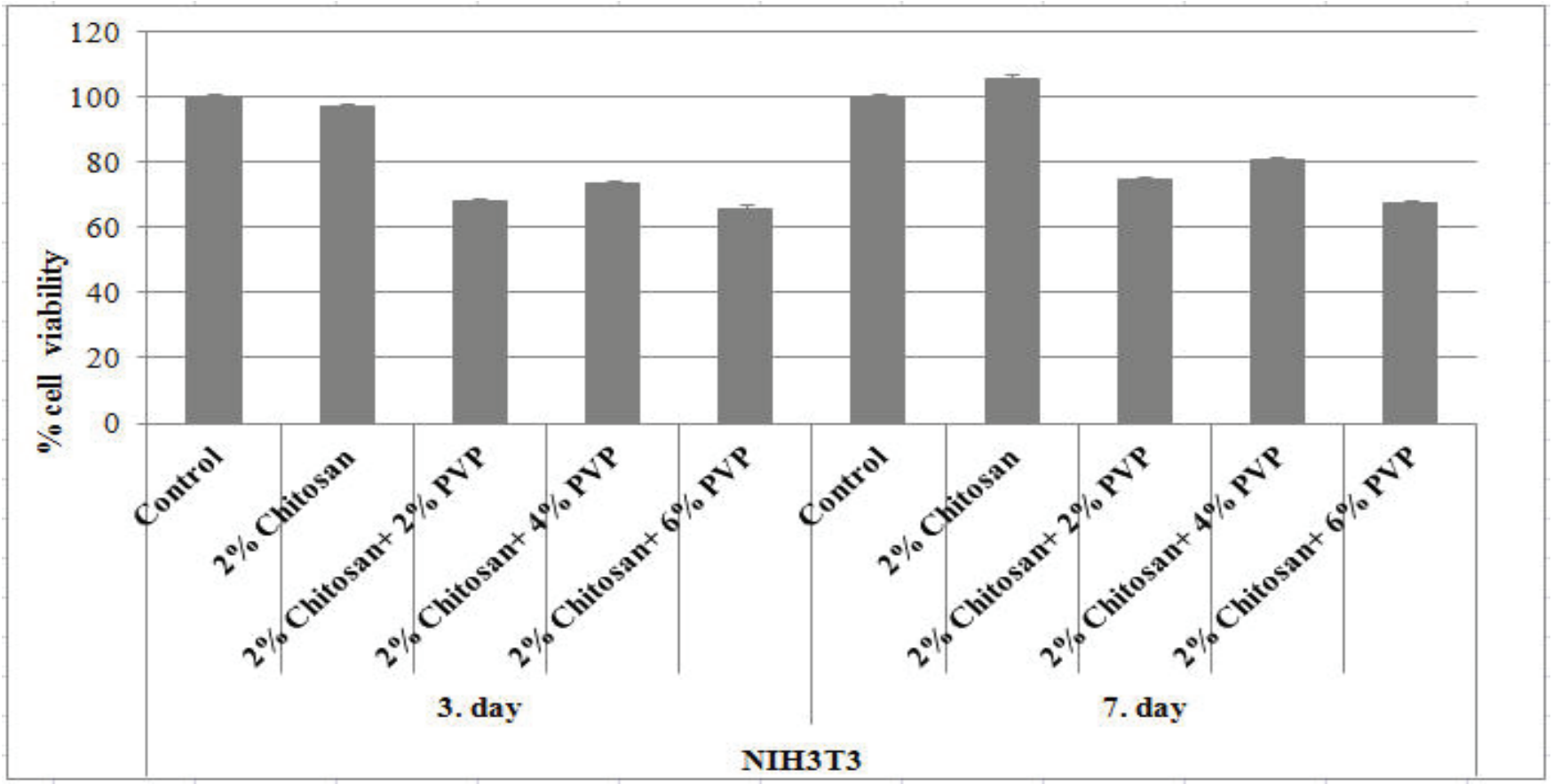

Figure 6. MTT assay results of hydrogels.

\section{The Effect to Cell Proliferation of Hydrogels}

MTT data, after 3 and 7 days of culturing, was used for the cell proliferation and viability (Fig. 6). The absorbance was markedly increased at day 7. pGM-CSF containing $2 \%$ chitosan $+4 \% \mathrm{PVP}$ hydrogel showed higher proliferation rate than the other hydrogels. Chitosan/PVP hydrogels did not induce significant cytotoxic effect that indicates the biocompatibility of the chitosan/PVP hydrogels. Jing et al. showed that chitosan modified PVP hydrogels had increased the cell attachment, growth and proliferation in MC3T3-E1 osteoblast cells (20).
pGM-CSF İçeren Kitozan/PVP Hidrojellerinin GM-CSF Ekspresyonu ve Fibroblast Proliferasyonuna Etkileri

\section{ÖZET}

$\mathrm{Bu}$ çalışmanın amacı, gen taşınması için pGM-CSF içeren kitozan/PVP hidrojel sistemini geliştirmektir. Yarı-interpenetre polimer ağ (yarı-IPN) yapısındaki hidrojeller, \%2 kitozan ve $\% 2, \% 4, \% 6$ PVP'nin glutaraldehitle çapraz bağlanması ile hazırlandi. Hidrojellerin viskozite, şişme özellikleri ve yüzey morfolojisi incelendi. Bu hidrojeller oldukça poroz yap1 gösterdi. PVP konsantrasyonunun artması ile porozite artt1. Viskozite hidrojellerin PVP konsantrasyonun artması ile azaldı. Şişme yüzdesi PVP konsantrasyonunun artması ile artış gösterdi. Hidrojellerin hücre tutunması ve proliferasyonuna

\section{CONCLUSION}

The results suggest that pGM-CSF loaded chitosan/PVP hydrogels increased cell attachment, growth and proliferation. These hydrogels are promising for gene delivery in tissue engineering and regenerative medicine applications.

etkisini incelemek için, NIH 3T3 fibroblast hücreleri kullanıldı. Hücreler, hidrojellerin yüzeyine tutundu. Bununla birlikte hücrelerin tutunması 1 ve 3 gün de yavaş olarak gerçeklești. 7 . ve 14. günlerde hücreler hidrojellerin yüzeyinde ve aralarında sağlıklı normal görünüşlü olup, proliferasyon gözlendi. ELISA çalışması ile en yüksek GM-CSF ekspresyonu pGM-CSF içeren \%2 kitozan+\%4PVP hidrojellerinde elde edildi. MTT çalışması ile kitozan/PVP hidrojellerinin önemli bir sitotoksik etkiyi indüklemediği gözlendi. Sonuç olarak, bu hidrojeller doku rejenerasyonunda lokal gen taşınması için aday taşıyıcı sistem olarak önerilebilir.

Anahtar Kelimeler: pGM-CSF, kitozan, PVP, hidrojel, gen taşınması 


\section{REFERENCES}

1. Ostrowska-Czubenko J, Gierszewska-Druzynska M. Effect of ionic crosslinking on the water state in hydrogel chitosan membranes. Carbohydr Polym 2009;77:590-8.

2. Bhattarai N, Gunn J, Zhang M. Chitosan-based hydrogels for controlled, localized drug delivery. Adv Drug Del Rev 2010;62:83-99.

3. Hong Y, Song H, Gong Y, Mao Z, Gao C, Shen J. Covalently crosslinked chitosan hydrogel: Properties of in vitro degradation and chondrocyte encapsulation. Acta Biomaterial 2007;3:23-31.

4. Ta HT, Han H, Larson I, Dass CR, Dunstan DE. Chitosandibasic orthophosphate hydrogel: A potential drug delivery system. Int J Pharm 2009;371:134-41.

5. Risbud M, Hardikar A, Bhonde R. Growth modulation of fibroblasts by chitosan-polyvinylpyrrolidone hydrogel: Implications for wound management? J Biosci 2000;25:25-31.

6. Anjum S, Arora A, Alam MS, Gupta B. Development of antimicrobial and scar preventive chitosan hydrogel wound dressings. Int J Pharm 2016;508:92-101.

7. Lei Y, Segura T. DNA delivery from matrix metalloproteinase degradable poly(ethylene glycol) hydrogels to mouse cloned mesenchymal stem cells. Biomaterials 2009;30:254-65.

8. Salva E, Ozbas-Turan S, Akbuğa J. Increased in vitro cell proliferation by chitosan/pGM-CSF complexes. Ind J Pharm Sci 2011;73:131-8.

9. Suknuntha K, Tantishaiyakul V, Worakul N, Taweepreda W. Characterization of muco- and bioadhesive properties of chitosan, PVP, and chitosan/PVP blends and release of amoxicillin from alginate beads coated with chitosan/PVP. Drug Develop Indust Pharm 2011; 37: 408-18.

10. Mishra RK, Datt M, Banthia AK. Synthesis and characterization of pectin/PVP hydrogel membranes for drug delivery system. AAPS PharmSciTech 2008;9: 395-403.

11. Chun KW, Lee JB, Kim SH, Park TG. Controlled release of plasmid DNA from photo-cross-linked pluronic hydrogels. Biomaterials 2005;26:3319-26.

12. Storrie H, Mooney DJ. Sustained delivery of plasmid DNA from polymeric scaffolds for tissue engineering. Adv Drug Del Rev 2006;58:500-14.

13. Laporte LD, Shea LD. Matrices and scaffolds for DNA delivery in tissue engineering. Adv Drug Del Rev 2007;59:292-307.

14. Lei Y, Huang S, Sharif-Kashani P, Chen Y, Kavehpour P, Segura T. Incorporation of active DNA/cationic polymer polyplexes into hydrogel scaffolds. Biomaterials 2010;31:9106-16.

15. Tokatlian T, Cam C, Segura T. Porous hyaluronic acid hydrogels for localized nonviral DNA delivery in a diabetic wound healing model. Adv Healthcare Mater 2015;4:1084-91.

16. Ji C, Khademhosseini A, Dehghani F. Enhancing cell penetration and proliferation in chitosan hydrogels for tissue engineering applications. Biomaterials 2011;32:9719-29.

17. Wu ZM, Zhang XG, Zheng C, Li CX, Zhang SM, Dong RN, Yu DM. Disulfide-crosslinked chitosan hydrogel for cell viability and controlled protein release. Eur J Pharm Sci 2009;37: 198206.

18. Archana D, Singh BK, Dutta J, Dutta PK. In vivo evaluation of chitosan-PVP-titanium dioxide nanocomposite as wound dressing material. Carbohydr Polym 2013;95:530-9.

19. Roy N, Saha N, Kitano T, Saha P. Novel hydrogels of PVPCMC and their swelling effect on viscoelastic properties. J App Polym Sci 2010;117:1703-10.

20. Jing X, Yuan G, Lijun K, Yandao G, Nanming Z, Xiufang Z. Behavior of MC3T3-E1 osteoblast cultured on chitosan modified with polyvinylpyrrolidone. Tsinghua Sci Technol 2005;10:439-44. 